SAINS TANAH - Journal of Soil Science and Agroclimatology

Journal homepage: http://jurnal.uns.ac.id/tanah

\title{
Metal ion toxicity and tolerance mechanisms in plants growing in acidic soil
}

\author{
Saradia Kar ${ }^{1}$, Raj Kishan Agrahari ${ }^{2}$, Sanjib Kumar Panda ${ }^{1 *}$ \\ ${ }^{1}$ Department of Biochemistry, Central University of Rajasthan, Bandarsindri, Ajmer 305817, India \\ ${ }^{2}$ Faculty of Biological Sciences, Gifu University, Japan
}

\begin{tabular}{|c|c|}
\hline ARTICLE INFO & ABSTRACT \\
\hline Keywords: & The abiotic factors have a wide effect on the growth of plants along with the cultivation \\
\hline Aluminum & of staple crops. The concentration of both essential and non-essential elements is \\
\hline Arsenic & impacted by the number of biogeochemical factors. The low $\mathrm{pH}(\leq 5.0)$ of the soil is one \\
\hline Detoxification & such factor that poses variation in the levels of metal ions and mostly it leads to metal \\
\hline $\begin{array}{l}\text { Iron } \\
\text { Metal toxicity }\end{array}$ & toxicity. The excess concentrations of the elements in the soil affect the growth, yield and \\
\hline Organic acid & $\begin{array}{l}\text { metabolic activities of the plants making them susceptible. However, some of the } \\
\text { genotypes adapt themselves to metal toxicity conditions by regulating their homeostatic }\end{array}$ \\
\hline Article history & genes leading to develop different strategies to undergo detoxification methods. In the \\
\hline Submitted: 2021-05-16 & present review we discuss the toxicity of $\mathrm{Al}, \mathrm{Fe}$, and As which is a non-essential metal, an \\
\hline Accepted: 2021-05-21 & essential metal and an unwanted heavy metal. In a broad picture, to escape the toxic \\
\hline Available online: 2021-06-30 & effects, plants have the strategy to exclude the excess metal outside the plant or include \\
\hline Published regularly: June 2021 & it in its storage cells. The insight of the present review aims at understanding these \\
\hline & strategies in detail which can be put into agricultural applications for developing better \\
\hline & \\
\hline
\end{tabular}

profskpanda73@gmail.com

How to Cite: Kar, S., Agrahari, R.K., Panda, S.K. (2021). Metal ion toxicity and tolerance mechanisms in plants growing in acidic soil [Review]. Sains Tanah Journal of Soil Science and Agroclimatology, 18(1): 107-114. https://dx.doi.org/10.20961/stjssa.v18i1.51254

\section{Introduction}

Soil $\mathrm{pH}$ is an important parameter that influences the availability of nutrients and elements for the plants directly or indirectly. The presence or absence of various mineral elements for plants is decided by the $\mathrm{pH}$ of the medium (Likar et al., 2015). Both acidity and alkalinity of the soil, therefore, can make the level of some important elements to fluctuate from their normal level which may lead to their toxicity or deficiency. Generally, $\mathrm{pH}$, lower than 7 is considered acidic and more than that is alkaline (AdamczykSzabela et al., 2015). The number of metal toxicities has been reported at $\mathrm{pH} 5.5$ and less than that for their effective mobility in low pH. Such type of soil includes the type of soil ultisols or oxisols and they are distributed in tropical and sub-tropical regions which are mainly responsible for the metal accumulations like iron (Fe) and aluminum (Al) (Blake \& Goulding, 2002; Sahrawat, 2005). A number of factors are responsible for soil acidification were polluting the soil by the utilization of fertilizers and other fossil energies plays a major role. The reduction of non-soluble form of metals into soluble form of ions is another major reason for the metal toxicity in plants. In addition, excessive uptake of cations over anions increases the proton content of the soil decreasing the soil pH in turn. Some of the important metals which reach toxicity level under low soil $\mathrm{pH}$ are $\mathrm{Fe}, \mathrm{Al}$ and Mn (Bojórquez-Quintal et al., 2017; Neina, 2019).

The toxicity of metal can be due to binding of metals with other plant proteins inhibiting its functions or excess accumulation can affect the uptake of some other essential elements by the plant (Hall, 2002). Under the effect of metal toxicity, the plants activate different metabolic pathways to overcome its susceptibility against the toxic effects. The adoption of the defense mechanism by the plants is an interesting aspect of their responses against stress. The plants achieve this mechanism through the number of strategies: by chelating and excluding the metal ions, by forming plaques around root by restricting the metal entry 
into the cells, by restricting the metals in the apoplastic region and by compartmentalization of the metal ions in the leaf tissue (Ovečka \& Takáč, 2014).

In the present review, we discuss about the toxicity of the metal ions $\mathrm{Fe}$, an essential micronutrient, $\mathrm{Al}$, important for its biological role but not an essential nutrient for plants and Arsenic (As), which is a heavy metal pollutant. We discuss here about the strategies which plant adopts to fight against these constraints together. Among the various strategies, the function of organic acids has been put to light which participates in mobilizing the metal ions inside or outside the plant.

\section{Plant-soil interactions: organic acid as metal chelators}

Plant interacts with the environment in many ways to access essential elements to sustain its development and growth. Soil is the prime source of such metal ions like Fe, $\mathrm{Cu}, \mathrm{Zn}, \mathrm{Mn}, \mathrm{Cd}, \mathrm{Co}, \mathrm{Ni}, \mathrm{B}$ and $\mathrm{Si}$ which are associated with the functionality of proteins, enzymes and transcription factors (Singh et al., 2016). In addition, there is number of non-essential heavy metals and beyond a specific concentration, they prove toxic for the plants. Al and As are two such metal ions alongside $\mathrm{Pb}, \mathrm{Cd}, \mathrm{Cr}$, and $\mathrm{Hg}$ (Chibuike \& Obiora, 2014). For the bioavailability of these metal ions plants exudes different classes of high and low molecular weighted compounds. Low molecular weight organic acids are abundantly released by the plants which are considered to be the natural chelators of metal ions (Montiel-Rozas et al., 2016). Their presence in the rhizosphere, increase or decrease the availability of the metal ions for the plants. The concentration of such organic acids varied from $0.5-10 \mu \mathrm{M}$ and they are present in a wide range. The most common exudates that have been reported are the ones involved in the tricarboxylic acid cycle, like oxalate, malate, citrate along with amino acids from other pathways like mugienic acids (Agnello et al., 2014; López-Bucio et al., 2000). However, the clarity of quantification of OAs available in the soil has not been able to be assessed perfectly as large number of these organic acids either proceeds as an intermediates or form soil colloids. The presence of the active chelators in the rhizosphere, therefore, depends upon the plant type, soil type, and the presence of metal ions in the surroundings (Adeleke et al., 2017).

Iron is the fourth most abundant microelement on Earth yet one-third of the globe suffers iron deficiency. For mobilization of iron in plants, they take up different strategies depending upon the form of the valency of the metal. The dicotyledonous plants take up Strategy-I where the reduction of $\mathrm{Fe}^{3+}$ to $\mathrm{Fe}^{2+}$ takes place. In monocotyledons, they undergo the Strategy-II method which includes the chelation method. In a region of calcareous and alkaline soil $\mathrm{pH}$, iron remains in its most insoluble form i.e. Fe (III). For facilitating the movement of the ions, the root exudes amino acids like mugienic acid which is better known as phytosiderphores (PS). The PS has a high affinity for $\mathrm{Fe}^{3+}$, the abundant form of iron in the soil, and therefore, forms a chelate complex. The formation of the chelated complex increases the solubility of $\mathrm{Fe}^{3+}$ for root acquisition (Dey et al., 2020). The main role for root acquisition is played by the specific transporters located on the membrane of the root epidermal cells. The Precursor of MAs are S-adenosine methionine molecules and forms a different range of mugienic acids like 2'-deoxymugineic acid (DMA), epihydroxymugineic acid (HMA), epihydroxy 2'deoxymugineic acid (HDMA) (Conte \& Walker, 2011; Zhang et al., 2019). Citrate is reported to be another primary organic acid that facilitates iron mobilization in the xylem of graminaceous plants. In addition, nicotinamine (NA) is another important iron chelator that leads to inter and intracellular movement of the iron in plants. The availability of the chelators in the rhizosphere region and then their uptake is made possible by the action of specific transporters located in epidermal cell membranes. Transporter of mugienic acid (TOM) family releases the PS in the rhizosphere. After the subsequent chelation process, the PS- $\mathrm{Fe}^{3+}$ complex is taken inside the cellular environment by separate transporters called Yellow Stripe Like (YSLS) proteins. YSL2 has been reported to be responsible for the transportation of Fe-NA complex and on the other hand, YSL15, YSL16 and YSL18 transport Fe-DMA complex across. For the transport of citrate across the membrane Ferric Reductase Defective3 (FRD3) belonging to the multidrug and toxic efflux (MATE) family participates which process the iron loading in the xylem (Wu et al., 2018) (Table 1).

Unlike $\mathrm{Fe}, \mathrm{Al}$ is not an essential element for plants however, stimulates root growth and enzyme activities. At neutral or higher $\mathrm{pH}$ of the soil, $\mathrm{Al}$ is present in its organic mineral complexes. As the $\mathrm{pH}$ decreases and reaches below 5.5, Al changes into its soluble mononuclear cationic form $\left(\mathrm{Al}^{3+}\right)$ which is toxic to plant growth. As a tolerance against $\mathrm{Al}$ toxicity, plants have two major mechanisms of Al resistance namely "exclusion" and "internal tolerance" (Eekhout et al., 2017). For the exclusion mechanism, the plant secretes different classes of organic acids such as, malate and citrate, which have a high affinity towards $\mathrm{Al}^{3+}$ and chelates $\mathrm{Al}$ in an insoluble form. Unlike iron uptake, the chelators in the case of Al lead to the insolubility of the ion for plant uptake and therefore, chelation is adapted as one of the tolerance mechanisms against Al toxicity by the plants. On the other hand, internal tolerance mechanisms were defined as those that reduce $A$ l toxicity and the resulting damage that occurs once. For example translocation of Al from roots to shoots through a well-reported $A B C$-transporter-like protein Aluminum Sensitive 3 (Larsen et al., 2005).

\section{Mechanisms underlying OAs excretion from roots}

The presence of organic acid in the root was discovered in the rhizosphere of lupin plants under phosphorous deficiency. Its presence had a synergistic effect on phosphorous acquisition and finally could overcome the stress consequences. The OA-metal ion complex shows a wide range of activities regulating metal transport (Kochian et al., 2004; Wu et al., 2018). On one hand, OA plays an important role in the acquisition of metal like iron (III) within the plant tissue during deficiency (Kobayashi \& Nishizawa, 2012) and on the other hand, the complex can also precipitate toxic forms of metals like Al. Hence, OA makes necessary nutrients available for the plants and also protects 
them from rhizotoxic metal ions. In addition to abiotic factors, biotic factors also remain responsible for maintaining a plant's development. The presence of rhizobacteria can have a positive effect on plant's growth and development as they participate in nutrient acquisition and promote growth. Recruitment of these bacteria in the rhizosphere takes place by chemotaxis through malate (Rudrappa et al., 2008). Hence, OAs maintain the microbial community of rhizosphere.

The formation of organic acids in the surrounding is assisted by the action of number of enzymes. Phosphoenolpyruvate carboxylase (PEPC) is an important enzyme to carry out the C4 cycle of dark reaction of photosynthesis where organic acids are formed as intermediates. It has been reported that under stress PEPC has been upregulated contributing 25 to $35 \%$ of carbon to the OAs like citrate and malate (Johnson et al., 1996). The altered method of citrate metabolism for citrate secretion is contributed by the action of increased citrate synthase (Anoop et al., 2003). Roots of soybean plants showed $16 \%$ increase in citrate synthase activity when exposed to excess Al (Yang et al., 2009). For the malate secretion, although, malate dehydrogenase showed no direct effect on $\mathrm{Al}$ exposure, however, malate synthase affected alternating the metabolic pathway. For the release of oxalic acid, the enzyme activities involved are not clear. For iron uptake, organic acids are more active during Fe deficient conditions $\mathrm{Fe}$ uptake. Even under Fe toxicity, the $\mathrm{Fe} 2+$ has to be transported to the sink tissues. The mobilization of iron takes place through a symplastic pathway by the help of the formation of $\mathrm{Fe}^{2+}$ - nicotinamine (NA) complex. NA is a precursor of mugienic acid and it is synthesized by the action of the enzyme Nicotinamine synthase (NAS). NA is also responsible for the chelation of other divalent cations (Bonneau et al., 2016; Connorton et al., 2017).

\section{Metal ion toxicity in plants:}

\subsection{Al toxicity and mechanism for detoxification}

Inhibition of root growth due to rhizotoxic $\mathrm{Al}^{3+}$ is one of the major limiting factors for reduced crop yield in acidic soil. Nearly, $60 \%$ of arable land in the world is acidic and therefore, Al toxicity is a worldwide problem for cultivators (Kochian et al., 2015). In recent years, there are number of crops with definite genotypic background which showed resistance to the toxicity and hence, have been utilized by the plant breeders to develop crops with enhanced resistance to $\mathrm{Al}^{3+}$ (Arunakumara et al., 2013). The molecular and physiological aspects of these resistant varieties have been put understudy to understand their mechanism of tolerance and the genes related to it (Aguilera et al., 2019). Research studies revealed number of such mechanisms with the plant either sequestering the toxic ion inside the plant tissue and compartmentalizing it or, arresting the ion in the rhizosphere by chelation process. There is another method followed by the plants where they allow Al to be stored in the cell wall of the root, however, the mechanism is not completely understood.

Studies in cereal crops have shown, once the plant let the entry of $\mathrm{Al}^{3+}$ in their tissue, multiple genes in root part gets up-regulated bringing cell wall modification, sequestration of $\mathrm{Al}$ in the respective cell wall or compartments and modification of root to shoot translocation of Al. The tolerance against $\mathrm{Al}$ is mostly ameliorated with secretion of organic acids in the rhizosphere by the plants (Kochian et al., 2004). In Triticum aestivum (wheat), the plant has been reported to release malate in the soil which has a strong affinity with $\mathrm{Al}^{3+}$ for extracellular chelation and hence, limit the movement of the ion within the plant by establishing a tolerance mechanism. The efflux of the OA is assisted by the Al-activated malate transporter (ALMT) situated on the plasma membrane of the root cells (Figure 1). The first tolerance gene for Al was discovered as TaALMT1 in wheat which was described as a novel anion channel. Following this, homologues of the gene were discovered in Arabidopsis as AtALMT1 and in Brassica napus as BnALMT1 and BnALMT2 (Li et al., 2014).

Table 1. Important transporters related to specific organic acids for mobilization of metal ions reported in model plants and their orthologs

\begin{tabular}{|c|c|c|c|c|}
\hline Transporters & $\begin{array}{l}\text { Metal-chelator } \\
\text { complex }\end{array}$ & Model & Orthologs / Homologs & Reference \\
\hline$A L M T$ & Malate & $\begin{array}{l}\text { Triticum } \\
\text { aestivum } \\
\text { (TaALMT1) }\end{array}$ & $\begin{array}{l}\text { Arabidopsis thaliana (AtALMT1) } \\
\text { Hordeum vulgare (HVALMT1) } \\
\text { Glycine max (GmALMT1) } \\
\text { Secale cereale (SCALMT1) } \\
\text { Medicago sativa (MsALMT1) } \\
\text { Brassica napus (BnALMT1) }\end{array}$ & $\begin{array}{l}\text { Delhaize et al. (2004); } \\
\text { Sasaki et al. (2004); } \\
\text { Sharma et al. (2016) }\end{array}$ \\
\hline MATE & Citrate & $\begin{array}{l}\text { Hordeum } \\
\text { vulgare } \\
\text { (HVACCT1) }\end{array}$ & $\begin{array}{l}\text { Oryza sativa (OsFRDL1) } \\
\text { Arabidopsis thaliana (AtMATE) } \\
\text { Sorghum bicolor (SbMATE) } \\
\text { Vaccinium corymbosum (VCMATE) }\end{array}$ & $\begin{array}{l}\text { Chen et al. (2015); } \\
\text { Durrett et al. (2007); } \\
\text { Santos et al. (2017) }\end{array}$ \\
\hline YSL & $\begin{array}{l}\text { Mugienic acid, } \\
\text { Deoxymugienic acid }\end{array}$ & $\begin{array}{l}\text { Zea mays } \\
\text { (ZmYS1) }\end{array}$ & $\begin{array}{l}\text { Oryza sativa (OsYSL15, OsYSL18, } \\
\text { OsYSL2) } \\
\text { Hordeum vulgare (HVYS1, HVYSL5) } \\
\text { Arabidopsis thaliana (AtYSL1, AtYSL2, } \\
\text { AtYSL3) }\end{array}$ & $\begin{array}{l}\text { Aoyama et al. (2009); } \\
\text { Inoue et al. (2009); } \\
\text { Zheng et al. (2011) }\end{array}$ \\
\hline TOM & Mugienic acid & $\begin{array}{l}\text { Oryza sativa } \\
\text { (OsTOM1) }\end{array}$ & $\begin{array}{l}\text { Arabidopsis thaliana(Zinc induced } \\
\text { facilitator-ZIF2) }\end{array}$ & (Nozoye et al., 2019) \\
\hline
\end{tabular}




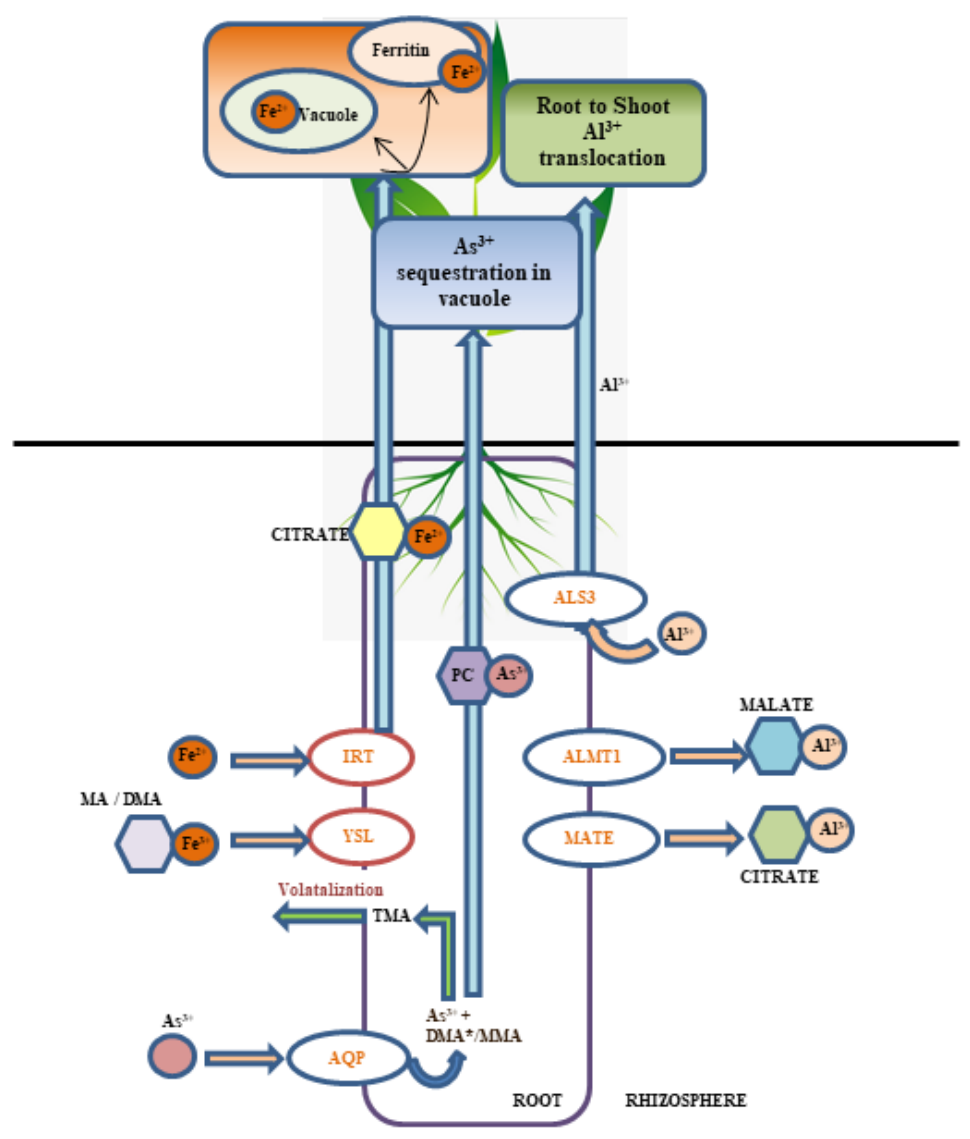

Figure 1. Mechanism of Aluminum, Iron and Arsenic detoxification and tolerance in plants. Transporters like ALMT1 and MATE excretes malate and citrate in the rhizosphere. The organic acids bind with the $\mathrm{Al}^{3+}$ and exclude them out of the root cells. The transporter ALS3, an ABC-transporter-like protein, functions to redistribute accumulated $\mathrm{Al}^{3+}$ away from sensitive tissues (root to shoot translocation) in order to protect the growing root from the toxic effects of $\mathrm{Al}^{3+}$. Iron is transported inside the root cells either in the form of Fe ${ }^{2+}$ through transporter IRT1, or in the form of $\mathrm{Fe}^{3+}$. The $\mathrm{Fe}^{3+}$ is chelated with the mugienic acid (MA)/ deoxymugienic acid (DMA) and is carried in the root cells through Yellow stripe like (YSLs) protein. Iron is carried through symplastic pathway in chelated form with citrate and sequestered in iron storage protein, ferritin or vacuole. $\mathrm{As}^{3+}$ enters the root cells through aquaporin (AQP) and binds with monomethylene arsenate (MMA)/ dimethylenearsenate (DMA*) to form trimethylene arsenate (TMA). TMA is volatile and moves out of the root cells. $\mathrm{As}^{3+}$ chelates with phytochelatins (PC) within the root medium and transported to shoot and gets sequestered in the vacuole

On the other hand, plants like barley, sorghum and maize have been reported to release citrate in their rhizosphere which performs a similar type of chelation. The exudation is carried out by MATE family transporters along with $\mathrm{H}^{+}$ antiport to maintain the $\mathrm{pH}$ of the medium. Numbers of factors are responsible for the OA availability in the medium. The presence of $\mathrm{Al}$ enhances the activity of the enzymes related to citrate and malate synthesis in addition to the overexpression of the ALMT1 and MATE transporters. The $\mathrm{pH}$ is another factor guiding the chelation as it has been noticed that at neutral $\mathrm{pH}$ citrate remains an effective chelator for $\mathrm{Al}^{3+}$ whereas, at acidic conditions, malate and oxalate are effective chelators. In crops like rice, the resistance against $\mathrm{Al}^{3+}$ is established by accumulating the ion in the root cell wall and through symplastic transport (Famoso et al., 2010) (Table 1). The component of the cell wall of the root cells is cellulose, pectin and hemicellulose. The pectin has a negatively charged carboxyl group attached through which it can bind $\mathrm{Ca}^{2+}$. The functional group has also a strong affinity for the trivalent ion of Al. During excess $\mathrm{Al}$ in the medium, the $\mathrm{Al}^{3+}$ binds with pectin making it much rigid and therefore, inhibits cell division. The pectins are basically converted into methylated pectins by the PMEs gene (pectin methylestaerases). In tolerant varieties of rice along with sorghum and rye showed low PME activity and higher $\mathrm{Al}$ binding with pectin. Another important plasma membranebound transporter, NRAT1, encodes a transporter mediating Al uptake from the root tip cell wall into the cell, where it is sequestered in the vacuole (Li et al., 2014). The gene belongs to the NRAMP family (Natural resistance-associated macrophage protein). During iron toxicity, the transporter has been reported to change its motifs for regulating aluminum uptake (Zhang et al., 2019). Unique genes like STAR1 and STAR2 form a complex that functions as an ABC transporter efflux out UDP-glucose into the cell wall 
alternating the carbohydrate composition of the cell wall changing the Al binding in rice (Huang et al., 2009).

\subsection{Fe toxicity and mechanism for detoxification}

The iron toxicity is concentrated in ultisols, oxisols and acid sulfate soil. Crops which are grown under wetland condition are more prone to iron toxicity due to the reduction of Fe (III) oxide hydrates to Fe (II) form of the ions under anoxic condition. The ferrous ion participates in redox reactions like Haber-Weiss and Fenton reaction to produce free radicals of superoxides and peroxides resulting in oxidative stress bringing cellular damage (Hell \& Stephan, 2003). To survive the excess iron toxic condition, some of the genotypes of different plants could resist the effect by adapting different tolerance strategies. These include restricting the $\mathrm{Fe}^{2+}$ uptake via root, sequestration of $\mathrm{Fe}$ in vacuoles or via storage proteins like ferritin and activating detoxifying enzymes reducing the oxidative damages. The first line of defense against iron toxicity is the enzyme oxidation at the root surface by releasing oxygen in the rhizosphere that creates a physical barrier for the ferrous ion called root plaque (Figure 1). The restriction of the ferrous ion uptake takes place in the rhizosphere where excess Fe (II) in the medium leads to the changes in root system architecture (RSA). Changing RSA is an important step to acclimatize against the adverse environmental condition. Excess Fe leads to inhibition of lateral root growth (Li et al., 2016). Number of QTLs involving series of FeTOX, have been reported by (Dufey et al., 2012; Wan et al., 2005; Wu et al., 2014) which are the prominent ones bringing physiological characterization under Fe toxic condition. However, colocalized QTLs have been reported commonly in chromosomes 3 and 5 of the resistant genotypes of rice involved in blocking the toxic QTLs or sub-channelling the excess $\mathrm{Fe}$ in vacuolar sequestration establishing Fe excess tolerance. In tolerant genotypes, the iron precipitates its excess iron in the apoplast region of the roots. As a result, Fe related transporters like OsIRT1, OsYSL, OsTOM, OsNRAMP, OsYSL15 are highly suppressed in the case of rice as reported (Aung \& Masuda, 2020). The iron toxicity related specific transcription factors (TFs) like WRKY is involved in regulating the number of morphological changes. In number of tolerant genotypes, WRKY TFs involved in root to shoot translocation has been reported to be repressed (Bashir et al., 2014). The efflux of organic acid like mugienic acid and deoxymugienic acid are mainly involved in the increased translocation of iron during iron deficiency. Nicotinamine is a strong chelator for metal cations including iron which is involved in $\mathrm{Fe}$ transport. In rice, the expression of a specific NA synthase gene, OsNAS3, has been reported to be induced during iron excess. The chelator is responsible to form a complex with excess Fe and effective sequestration to form a defense mechanism (Aung \& Masuda, 2020). Muller and Nowack (2010), showed that complexes like Fe-citrate increases the translocation from root to shoot without generating toxic effects. However, artificial chelators like EDTA have a more drastic effect.

Other than the tolerance response by the genotype itself, some common agricultural practices can be adopted to reduce the excess iron effect in the medium. An effective amelioration method in the field is to carry out periodic drainage to avoid the anoxic condition. To normalize the soil $\mathrm{pH}$ liming can also be done. Deficiencies of some micronutrients like $\mathrm{P}, \mathrm{K}, \mathrm{Ca}$ and $\mathrm{Mg}$ have been reported to increase iron toxicity (Fageria et al., 2008). However, it has also been reported that plants also undergo amelioration by $\mathrm{K}^{+}$uptake. In an experiment by Li et al. (2016), they have shown the lateral root formation with excess $\mathrm{Fe}^{2+}$ in the medium by alleviating $\mathrm{K}^{+}$uptake.

\subsection{As toxicity and mechanism for detoxification}

Arsenic (As) is a non-essential heavy metal for plants and its uptake is mainly dependent upon speciation of As toxicity in the environment which can be due to natural processes of weathering of rocks, volcanic activity, mining, smelting and use of As based fertilizers. As is present in four different oxidation states- As (III), As(0), As(III), and As(V). The most toxic form is the inorganic form i.e arsenate $\left(\mathrm{As}^{5+}\right)$ prevailing under reduced conditions and arsenite $\left(\mathrm{As}^{3+}\right)$ prevailing under oxidized form (Khalid et al., 2017). These inorganic forms of As can easily be taken up by the transporters like $\mathrm{Pi}$ transporter protein (PHT) and nodulin intrinsic protein. PHT is present in the plasma membrane of root cells which is also involved in inorganic phosphate transport. The effect of the heavy metal ion is highly drastic for plants at the physiological, biochemical and molecular levels. Severe ROS production leads to unrepairable damages.

As stress can provoke a number of toxic effects, plants develop physiological and biochemical changes that reduce the root to shoot transport of the metal (Pourrut et al., 2011). The number of metal-binding factors like metallothioneins and phytochelatins is engaged in detoxification by binding with As. The complex helps in transport and vacuolar sequestration. Its involvement in detoxification was confirmed in rice cultivars where the content of PCs increased with increased As tolerance (AlHuqail et al., 2017). Another inorganic compound involved in detoxification of As is Nitric oxide (NO) as it has been reported as ROS scavenger. NO has been reported to be a detoxifying agent in various plants as it can protect plants against As and several toxic elements. In rice plants, it has been observed that under external application of NO, reduced As uptake from the root has taken place till shoot (Singh et al., 2017). In parallel, the external application of salicylic acid has a similar effect against As transport. Methylation of toxic As(III) is another important method of detoxification that previously was reported in microorganisms and later were also found in plants. The process leads to the conversion of the ion into a methylated compound like trimethylarsine (TMA) which is volatile in nature and gets transported from the root cells to the medium (Figure 1) (Srivastava et al., 2012; Xu et al., 2007).

\section{Conclusion and future perspective}

The majority of crop yield has been affected by the presence of heavy metals in the surroundings. Their presence can be for various reasons including, high waterlogged condition, soil $\mathrm{pH}$ and other methods of speciation. However, plants have evolved different 
mechanisms to adapt against heavy metals stress by physiological, biochemical and molecular modifications. The methods of tolerance were grown at multiple levels. ROS effects are common in each case of $\mathrm{Al}, \mathrm{Fe}$ and As stress and their mitigation against the stress is to activate the antioxidant enzymes like SOD, POD, CAT, APX, and GR catalyzing the breakdown of the harmful ROS. Al and Fe are required at lower quantities for the plant's normal functioning and growth. Therefore, a prominent tolerance mechanism in both cases is to regulate the transporters. There are a specific family of transporters which participates in excluding the excess metal ion from the plant. In the case of As, being it non-essential, however, transporters involved in transporting metal cations also develop an affinity towards cationic As. The formation of a complex of the toxic form of metal with chelators and other metal-binding factors is another way to develop a tolerance mechanism. The number of transcriptome analyses has put forward the concept of tolerance at the genetic level where number of genes related to transporters are repressed to reduce the root to shoot transport during excess availability of the metals in the surroundings. The signalling and homeostatic pathway of $\mathrm{Al}$ and Fe under abiotic stress have been the most discussed topic in recent years and much of the portion has been understood. In case of As still studies are carried out and the transporters mobilizing the metal is not widely explained. Understanding the different mechanisms of tolerance in each case will help us in future agricultural prospects for the crops growing under varying metal stress. In the case of essential micronutrients like Fe, the study would also help us in knowing the fundamental mechanisms of sequestration in plant tissues which in turn, would allow us to develop bio-fortified plants.

\section{Declaration of Competing Interest}

The authors declare no competing financial or personal interests that may appear and influence the work reported in this paper.

\section{References}

Adamczyk-Szabela, D., Markiewicz, J., \& Wolf, W. M. (2015). Heavy Metal Uptake by Herbs. IV. Influence of Soil pH on the Content of Heavy Metals in Valeriana officinalis L. Water, Air, \& Soil Pollution, 226(4), 106. https://doi.org/10.1007/s11270-015-2360-3

Adeleke, R., Nwangburuka, C., \& Oboirien, B. (2017). Origins, roles and fate of organic acids in soils: A review. South African Journal of Botany, 108, 393-406. https://doi.org/10.1016/j.sajb.2016.09.002

Agnello, A. C., Huguenot, D., Van Hullebusch, E. D., \& Esposito, G. (2014). Enhanced Phytoremediation: A Review of Low Molecular Weight Organic Acids and Surfactants Used as Amendments. Critical Reviews in Environmental Science and Technology, 44(22), 25312576.

https://doi.org/10.1080/10643389.2013.829764

Aguilera, J. G., Teodoro, P. E., da Silva Junior, J. P., Pereira, J. F., Zuffo, A. M., \& Consoli, L. (2019). Selection of Aluminum-Resistant Wheat Genotypes Using
Multienvironment and Multivariate Indices. Agronomy Journal, 111(6), 2804-2810. https://doi.org/10.2134/agronj2019.06.0470

Al-Huqail, A. A., Al-Rashed, S. A., Ibrahim, M. M., El-Gaaly, G. A., \& Qureshi, M. I. (2017). Arsenic induced ecophysiological changes in Chickpea (Cicer arietinum) and protection by gypsum, a source of sulphur and calcium. Scientia Horticulturae, 217, 226-233. https://doi.org/https://doi.org/10.1016/j.scienta.201 7.02.007

Anoop, V. M., Basu, U., McCammon, M. T., McAlister-Henn, L., \& Taylor, G. J. (2003). Modulation of citrate metabolism alters aluminum tolerance in yeast and transgenic canola overexpressing a mitochondrial citrate synthase. Plant physiology, 132(4), 2205-2217. https://doi.org/10.1104/pp.103.023903

Aoyama, T., Kobayashi, T., Takahashi, M., Nagasaka, S., Usuda, K., Kakei, Y., Ishimaru, Y., Nakanishi, H., Mori, S., \& Nishizawa, N. K. (2009). OsYSL18 is a rice iron(III)-deoxymugineic acid transporter specifically expressed in reproductive organs and phloem of lamina joints. Plant $\mathrm{Mol} \mathrm{Biol,} \mathrm{70(6),} \mathrm{681-692.}$ https://doi.org/10.1007/s11103-009-9500-3

Arunakumara, K. K. I. U., Walpola, B. C., \& Yoon, M.-H. (2013). Aluminum toxicity and tolerance mechanism in cereals and legumes - A review. Journal of the Korean Society for Applied Biological Chemistry, 56(1), 1-9. https://doi.org/10.1007/s13765-012-2314-z

Aung, M. S., \& Masuda, H. (2020). How Does Rice Defend Against Excess Iron?: Physiological and Molecular Mechanisms [Mini Review]. Frontiers in Plant Science, 11(1102). https://doi.org/10.3389/fpls.2020.01102

Bashir, K., Hanada, K., Shimizu, M., Seki, M., Nakanishi, H., \& Nishizawa, N. K. (2014). Transcriptomic analysis of rice in response to iron deficiency and excess. Rice, 7(1), 18. https://doi.org/10.1186/s12284-014-0018-1

Blake, L., \& Goulding, K. W. T. (2002). Effects of atmospheric deposition, soil $\mathrm{pH}$ and acidification on heavy metal contents in soils and vegetation of semi-natural ecosystems at Rothamsted Experimental Station, UK. Plant and Soil, 240(2), 235-251. https://doi.org/10.1023/A:1015731530498

Bojórquez-Quintal, E., Escalante-Magaña, C., EchevarríaMachado, I., \& Martínez-Estévez, M. (2017). Aluminum, a Friend or Foe of Higher Plants in Acid Soils [Review]. Frontiers in Plant Science, 8(1767). https://doi.org/10.3389/fpls.2017.01767

Bonneau, J., Baumann, U., Beasley, J., Li, Y., \& Johnson, A. A. (2016). Identification and molecular characterization of the nicotianamine synthase gene family in bread wheat. Plant Biotechnol J, 14(12), 2228-2239. https://doi.org/10.1111/pbi.12577

Chen, L., Liu, Y., Liu, H., Kang, L., Geng, J., Gai, Y., Ding, Y., Sun, H., \& Li, Y. (2015). Identification and expression analysis of MATE genes involved in flavonoid transport in blueberry plants. PLoS One, 10(3), e0118578.

https://doi.org/10.1371/journal.pone.0118578

Chibuike, G. U., \& Obiora, S. C. (2014). Heavy Metal Polluted Soils: Effect on Plants and Bioremediation Methods. 
Applied and Environmental Soil Science, 2014, 752708. https://doi.org/10.1155/2014/752708

Connorton, J. M., Balk, J., \& Rodríguez-Celma, J. (2017). Iron homeostasis in plants - a brief overview. Metallomics : integrated biometal science, 9(7), 813-823. https://doi.org/10.1039/c7mt00136c

Conte, S. S., \& Walker, E. L. (2011). Transporters contributing to iron trafficking in plants. Mol Plant, 4(3), 464-476. https://doi.org/10.1093/mp/ssr015

Delhaize, E., Ryan, P. R., Hebb, D. M., Yamamoto, Y., Sasaki, T., \& Matsumoto, H. (2004). Engineering high-level aluminum tolerance in barley with the ALMT1 gene. Proceedings of the National Academy of Sciences of the United States of America, 101(42), 15249-15254. https://doi.org/10.1073/pnas.0406258101

Dey, S., Regon, P., Kar, S., \& Panda, S. K. (2020). Chelators of iron and their role in plant's iron management. Physiology and Molecular Biology of Plants, 26(8), 1541-1549. https://doi.org/10.1007/s12298-02000841-y

Dufey, I., Hiel, M.-P., Hakizimana, P., Draye, X., Lutts, S., Koné, B., Dramé, K. N., Konaté, K. A., Sie, M., \& Bertin, P. (2012). Multienvironment Quantitative Trait Loci Mapping and Consistency across Environments of Resistance Mechanisms to Ferrous Iron Toxicity in Rice. Crop Science, 52(2), 539-550. https://doi.org/https://doi.org/10.2135/cropsci2009. 09.0544

Durrett, T. P., Gassmann, W., \& Rogers, E. E. (2007). The FRD3-mediated efflux of citrate into the root vasculature is necessary for efficient iron translocation. Plant physiology, 144(1), 197-205. https://doi.org/10.1104/pp.107.097162

Eekhout, T., Larsen, P., \& De Veylder, L. (2017). Modification of DNA Checkpoints to Confer Aluminum Tolerance. Trends in Plant Science, 22(2), 102-105. https://doi.org/https://doi.org/10.1016/j.tplants.201 6.12 .003

Fageria, N. K., Santos, A. B., Barbosa Filho, M. P., \& Guimarães, C. M. (2008). Iron Toxicity in Lowland Rice. Journal of Plant Nutrition, 31(9), 1676-1697. https://doi.org/10.1080/01904160802244902

Famoso, A. N., Clark, R. T., Shaff, J. E., Craft, E., McCouch, S. R., \& Kochian, L. V. (2010). Development of a Novel Aluminum Tolerance Phenotyping Platform Used for Comparisons of Cereal Aluminum Tolerance and Investigations into Rice Aluminum Tolerance Mechanisms Plant physiology, 153(4), 1678-1691. https://doi.org/10.1104/pp.110.156794

Hall, J. L. (2002). Cellular mechanisms for heavy metal detoxification and tolerance. Journal of Experimental Botany, 53(366), 1-11. https://doi.org/10.1093/jexbot/53.366.1

Hell, R., \& Stephan, U. W. (2003). Iron uptake, trafficking and homeostasis in plants. Planta, 216(4), 541-551. https://doi.org/10.1007/s00425-002-0920-4

Huang, C. F., Yamaji, N., Mitani, N., Yano, M., Nagamura, Y., \& Ma, J. F. (2009). A bacterial-type ABC transporter is involved in aluminum tolerance in rice. The Plant cell,
21(2),

https://doi.org/10.1105/tpc.108.064543

655-667.

Inoue, H., Kobayashi, T., Nozoye, T., Takahashi, M., Kakei, Y., Suzuki, K., Nakazono, M., Nakanishi, H., Mori, S., \& Nishizawa, N. K. (2009). Rice OsYSL15 is an ironregulated iron(III)-deoxymugineic acid transporter expressed in the roots and is essential for iron uptake in early growth of the seedlings. J Biol Chem, 284(6), 3470-3479. https://doi.org/10.1074/jbc.M806042200

Johnson, J. F., Vance, C. P., \& Allan, D. L. (1996). Phosphorus Deficiency in Lupinus albus (Altered Lateral Root Development and Enhanced Expression of Phosphoenolpyruvate Carboxylase). Plant physiology, 112(1), 31-41. https://doi.org/10.1104/pp.112.1.31

Khalid, S., Shahid, M., Niazi, N. K., Rafiq, M., Bakhat, H. F., Imran, M., Abbas, T., Bibi, I., \& Dumat, C. (2017). Arsenic behaviour in soil-plant system: Biogeochemical reactions and chemical speciation influences. In Enhancing cleanup of environmental pollutants (pp. 97-140). Springer. https://doi.org/10.1007/978-3-319-55423-5_4

Kobayashi, T., \& Nishizawa, N. K. (2012). Iron Uptake, Translocation, and Regulation in Higher Plants. Annual Review of Plant Biology, 63(1), 131-152. https://doi.org/10.1146/annurev-arplant-042811105522

Kochian, L. V., Hoekenga, O. A., \& Piñeros, M. A. (2004). HOW DO CROP PLANTS TOLERATE ACID SOILS? MECHANISMS OF ALUMINUM TOLERANCE AND PHOSPHOROUS EFFICIENCY. Annual Review of Plant Biology, 55(1), 459-493. https://doi.org/10.1146/annurev.arplant.55.031903.1 41655

Kochian, L. V., Piñeros, M. A., Liu, J., \& Magalhaes, J. V. (2015). Plant Adaptation to Acid Soils: The Molecular Basis for Crop Aluminum Resistance. Annual Review of Plant Biology, 66(1), 571-598. https://doi.org/10.1146/annurev-arplant-043014114822

Larsen, P. B., Geisler, M. J., Jones, C. A., Williams, K. M., \& Cancel, J. D. (2005). ALS3 encodes a phloem-localized $A B C$ transporter-like protein that is required for aluminum tolerance in Arabidopsis. Plant J, 41(3), 353-363. https://doi.org/10.1111/j.1365313X.2004.02306.x

Li, G., Kronzucker, H. J., \& Shi, W. (2016). Root developmental adaptation to Fe toxicity: Mechanisms and management. Plant Signaling \& Behavior, 11(1), e1117722.

https://doi.org/10.1080/15592324.2015.1117722

Li, J.-Y., Liu, J., Dong, D., Jia, X., McCouch, S. R., \& Kochian, L. V. (2014). Natural variation underlies alterations in Nramp aluminum transporter (\&lt;em\&gt;NRAT1\&lt;/em\&gt;) expression and function that play a key role in rice aluminum tolerance. Proceedings of the National Academy of Sciences, 111(17), 6503. https://doi.org/10.1073/pnas.1318975111

Likar, M., Vogel-Mikuš, K., Potisek, M., Hančević, K., Radić, T., Nečemer, M., \& Regvar, M. (2015). Importance of 
soil and vineyard management in the determination of grapevine mineral composition. Science of The Total Environment, 505, 724-731. https://doi.org/10.1016/j.scitotenv.2014.10.057

López-Bucio, J., Nieto-Jacobo, M. a. F., Ramírez-Rodríguez, V., \& Herrera-Estrella, L. (2000). Organic acid metabolism in plants: from adaptive physiology to transgenic varieties for cultivation in extreme soils. Plant Science, 160(1), 1-13. https://doi.org/10.1016/S0168-9452(00)00347-2

Montiel-Rozas, M. M., Madejón, E., \& Madejón, P. (2016). Effect of heavy metals and organic matter on root exudates (low molecular weight organic acids) of herbaceous species: An assessment in sand and soil conditions under different levels of contamination. Environmental Pollution, 216, 273-281. https://doi.org/10.1016/j.envpol.2016.05.080

Muller, N. C., \& Nowack, B. (2010). Nano zero valent iron THE solution for water and soil remediation? Observatory NANO Focus Report, Netherlands. https://www.yumpu.com/en/document/read/61049 45/nano-zero-valent-iron-the-solution-for-water-andsoil-remediation

Neina, D. (2019). The Role of Soil pH in Plant Nutrition and Soil Remediation. Applied and Environmental Soil Science, 2019, 5794869. https://doi.org/10.1155/2019/5794869

Nozoye, T., von Wirén, N., Sato, Y., Higashiyama, T., Nakanishi, H., \& Nishizawa, N. K. (2019). Characterization of the Nicotianamine Exporter ENA1 in Rice [Original Research]. Frontiers in Plant Science, 10(502). https://doi.org/10.3389/fpls.2019.00502

Ovečka, M., \& Takáč, T. (2014). Managing heavy metal toxicity stress in plants: Biological and biotechnological tools. Biotechnology Advances, 32(1), 73-86. https://doi.org/10.1016/j.biotechadv.2013.11.011

Pourrut, B., Shahid, M., Dumat, C., Winterton, P., \& Pinelli, E. (2011). Lead uptake, toxicity, and detoxification in plants. Rev Environ Contam Toxicol, 213, 113-136. https://doi.org/10.1007/978-1-4419-9860-6_4

Rudrappa, T., Czymmek, K. J., Paré, P. W., \& Bais, H. P. (2008). Root-Secreted Malic Acid Recruits Beneficial Soil Bacteria Plant physiology, 148(3), 1547-1556. https://doi.org/10.1104/pp.108.127613

Sahrawat, K. L. (2005). Iron Toxicity in Wetland Rice and the Role of Other Nutrients. Journal of Plant Nutrition, 27(8), 1471-1504. https://doi.org/10.1081/PLN200025869

Santos, A. L. d., Chaves-Silva, S., Yang, L., Maia, L. G. S., Chalfun-Júnior, A., Sinharoy, S., Zhao, J., \& Benedito, V. A. (2017). Global analysis of the MATE gene family of metabolite transporters in tomato. BMC Plant Biology, 17(1), 185. https://doi.org/10.1186/s12870017-1115-2

Sasaki, T., Yamamoto, Y., Ezaki, B., Katsuhara, M., Ahn, S. J., Ryan, P. R., Delhaize, E., \& Matsumoto, H. (2004). A wheat gene encoding an aluminum-activated malate transporter. Plant J, 37(5), 645-653. https://doi.org/10.1111/j.1365-313x.2003.01991.x

Sharma, T., Dreyer, I., Kochian, L., \& Piñeros, M. A. (2016). The ALMT Family of Organic Acid Transporters in Plants and Their Involvement in Detoxification and Nutrient Security [Review]. Frontiers in Plant Science, 7(1488). https://doi.org/10.3389/fpls.2016.01488

Singh, P. K., Indoliya, Y., Chauhan, A. S., Singh, S. P., Singh, A. P., Dwivedi, S., Tripathi, R. D., \& Chakrabarty, D. (2017). Nitric oxide mediated transcriptional modulation enhances plant adaptive responses to arsenic stress. Scientific Reports, 7(1), 3592. https://doi.org/10.1038/s41598-017-03923-2

Singh, S., Parihar, P., Singh, R., Singh, V. P., \& Prasad, S. M. (2016). Heavy Metal Tolerance in Plants: Role of Transcriptomics, Proteomics, Metabolomics, and Ionomics [Review]. Frontiers in Plant Science, 6(1143). https://doi.org/10.3389/fpls.2015.01143

Srivastava, S., Suprasanna, P., \& D'Souza, S. F. (2012). Mechanisms of Arsenic Tolerance and Detoxification in Plants and their Application in Transgenic Technology: A Critical Appraisal. International Journal of Phytoremediation, 14(5), 506-517. https://doi.org/10.1080/15226514.2011.604690

Wan, J. L., Zhai, H. Q., \& Wan, J. M. (2005). Mapping of QTLS for ferrous iron toxicity tolerance in rice (Oryza sativa L.). Yi Chuan Xue Bao, 32(11), 1156-1166.

Wu, L.-B., Shhadi, M. Y., Gregorio, G., Matthus, E., Becker, M., \& Frei, M. (2014). Genetic and physiological analysis of tolerance to acute iron toxicity in rice. Rice (New York, N.Y.), 7(1), 8-8. https://doi.org/10.1186/s12284-014-0008-3

Wu, L., Kobayashi, Y., Wasaki, J., \& Koyama, H. (2018). Organic acid excretion from roots: a plant mechanism for enhancing phosphorus acquisition, enhancing aluminum tolerance, and recruiting beneficial rhizobacteria. Soil Science and Plant Nutrition, 64(6), 697-704. https://doi.org/10.1080/00380768.2018.1537093

Xu, X. Y., McGrath, S. P., \& Zhao, F. J. (2007). Rapid reduction of arsenate in the medium mediated by plant roots. New Phytol, 176(3), 590-599. https://doi.org/10.1111/j.1469-8137.2007.02195.x

Yang, Z. B., You, J. F., Xu, M. Y., \& Yang, Z. M. (2009). Interaction between aluminum toxicity and manganese toxicity in soybean (Glycine max). Plant and Soil, 319(1), 277-289. https://doi.org/10.1007/s11104-008-9869-9

Zhang, X., Zhang, D., Sun, W., \& Wang, T. (2019). The Adaptive Mechanism of Plants to Iron Deficiency via Iron Uptake, Transport, and Homeostasis. International journal of molecular sciences, 20(10), 2424. https://doi.org/10.3390/ijms20102424

Zheng, L., Fujii, M., Yamaji, N., Sasaki, A., Yamane, M., Sakurai, I., Sato, K., \& Ma, J. F. (2011). Isolation and Characterization of a Barley Yellow Stripe-Like Gene, HvYSL5. Plant and Cell Physiology, 52(5), 765-774. https://doi.org/10.1093/pcp/pcr009 